\title{
Detection and Evaluation of Antibodies to SARS CoV-2 Spike Protein in Healthcare Workers After Inactivated COVID-19 (CoronaVac) Vaccination
}

\author{
Derap Demir Tekol, ${ }^{1}$ (1) Mehmet Mustafa Altıntaş,2 (10) Erdal Yılmaz, ${ }^{3}$ \\ (1) Kemal Saracoglu, ${ }^{4}$ (1) Recep Demirhan ${ }^{5}$
}

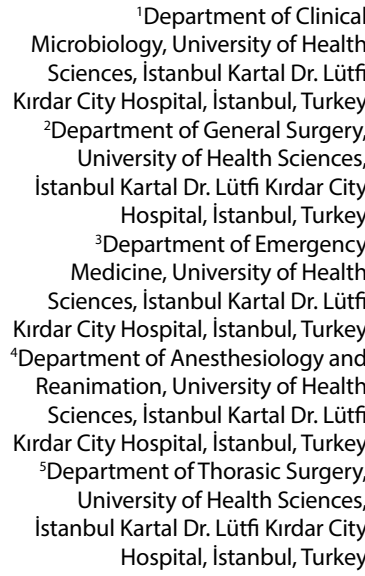

Submitted: 17.08.2021 Accepted: 18.08.202

Correspondence: Serap Demir Tekol, SBÜ, İstanbul Kartal Dr. Lütfi Kırdar Şehir Hastanesi, Mikrobiyoloji Bölümü, İstanbul, Turkey

E-mail: serapdemir@yahoo.com

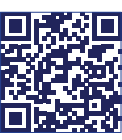

Keywords: Antibody detection; CoronaVAC; immunity; inactivated vaccine; SARS-CoV-2.

\section{(cc) (P) $\$$ \\ This work is licensed under a Creative Common Attribution-NonCommercial 4.0 International License.}

\begin{abstract}
Objective: Antibodies against the $S$ protein are used to investigate post-vaccine and post-infection immunity. In this study, it was aimed to determine the antibody levels and the efficacy of the vaccine after the CoronaVac vaccine in healthcare workers.
\end{abstract}

Methods: Data from 96 healthcare workers who had the CoronaVac vaccine were analyzed. From the first dose, monthly antibody measurements were made over a 5-months period with an interval of 28 days between two vaccine doses. Total antibodies ( $\lg M$ and $\lg G$ ) against SARS-CoV-2 were detected by the Electrochemiluminescence method using the Elecsys ${ }^{\circledR}$ Anti-SARS-CoV-2 S kit, which contains recombinant protein representing the receptor-binding site of the SI antigen.

Results: $51 \%(n=49)$ of the volunteers aged 22-69 (39.75 \pm 11.19$)$ were female. The mean antibody concentration was $8.93 \mathrm{U} / \mathrm{mL}$ one month after the first vaccine dose, 17I.30 IU/ $\mathrm{mL}$ one month after the second vaccine dose, $125.90 \mathrm{IU} / \mathrm{mL}$ two months after the second dose, $98.57 \mathrm{IU}$ three months later, and $89.85 \mathrm{IU} / \mathrm{mL}$ after four months. Increase in antibody levels in the first and second months; The decreases in antibody levels in the in the following months were statistically significant. The proportion of subjects with antibody positivity $\geq 0.8 \mathrm{IU} / \mathrm{mL}$ and developing neutralizing antibodies $(\geq 15 \mathrm{IU} / \mathrm{mL}$ ) was $68.75 \%$ and $5.21 \%$ after the first dose of vaccination. The rate of individuals developing neutralizing antibodies were $100 \%, 93.8 \%, 91.7 \%$, and $89.6 \%$ with regard to the months after the second dose of vaccination. One person had SARS-CoV-2 D3L-containing variant (UK variant) PCR positivity 9 weeks after the second vaccine dose.

Conclusion: In the long-term follow-up, the neutralizing antibody level was found to be significantly higher even at the end of the 5 th month, indicating that the vaccine is protective. The decrease in post-vaccination antibody concentrations and the emergence of new SARSCOV-2 variants suggest that a booster dose may be beneficial.

\section{INTRODUCTION}

Despite the control measures implemented all over the world, Coronavirus Disease 2019 (COVID-19) continues to spread. ${ }^{[l]}$ According to the data of the World Health Organization (WHO) dated 14 August 2021, 205.338.159 cases and 4.333.094 deaths were reported, and 4.428. 168.759 doses of vaccine were administered. ${ }^{[2]}$

COVID- 19 causes humoral immune response and antibody production against specific viral antigens such as $\mathrm{N}$ protein and $\mathrm{S}$ protein. ${ }^{[3]}$ Since the beginning of the outbreak, more than 198 vaccines developed or in clinical development for COVID- 19 have been reported. ${ }^{[4]}$ 
These include inactivated vaccines, recombinant protein vaccines, vectored vaccines, live virus vaccines, and DNA or RNA vaccines. Seroconversion occurs approximately two weeks later. ${ }^{[5]}$ However, little is known about the successful induction of a protective immune response. This obscurity leads to distrust and non-acceptance towards vaccines in society. In a multicenter study conducted in African and Middle Eastern countries, it was reported that $33.19 \%$ of the population did not consider getting vaccinated. ${ }^{[6]}$ In another study conducted in England and Turkey, the rate of those who were hesitant about the vaccine was found to be $31 \%$ and $14 \%$, respectively, and $3 \%$ of the participants refused to be vaccinated. ${ }^{[7]}$ Reasons such as fear of side effects and the thought of being infected with the vaccine are effective. ${ }^{[8]}$ However, vaccination is known to reduce hospitalization, severe disease, and mortality rates. ${ }^{[9]}$ To protect the global community from the threat of morbidity and mortality from SARS-CoV-2, the safety, and efficacy of the vaccine must be revealed for vaccinating individuals.

The first vaccine administered in our country is the adsorbed COVID-19 vaccine, approved for emergency use by the Ministry of Health, and CoronaVac (Sinovac Life Sciences, Beijing) containing $3 \mu \mathrm{g} / 0.5 \mathrm{~mL}$ (600 SU/dose) inactivated SARS-CoV-2 virus and aluminum hydroxide as an adjuvant, China vaccine. The vaccination protocol was administered in 2 doses with an interval of 4 weeks. This prospective, observational, clinical study aimed to investigate antibody levels and efficacy of antibodies that develop after the CoronaVac vaccine in healthcare workers.

\section{MATERIALS AND METHODS}

\section{Study design}

Following the approval of the Ethics Committee (24.02.2021, protocol number: 514/196/20), this study was designed as a prospective, observational, single-centered. Individuals working in University of Health Sciences, İstanbul Kartal Dr. Lütfi Kırdar City Hospital as healthcare professionals and scheduled to receive two doses of the CoronaVac vaccine were invited via e-mail to participate in the study. Age, gender, and body mass index (BMI) parameters of the volunteers participating in the study were recorded. The history of influenza vaccination before the COVID- I 9 vaccination was questioned and recorded.

Exclusion criteria included having COVID-19 infection prior to vaccination, suspected symptoms such as fever, cough, shortness of breath, sore throat, headache, muscle pain, loss of taste or smell, and diarrhea.

\section{Antibody measurements}

Two doses of the vaccine were administered with an interval of 28 days. Antibody measurements were made with one-month intervals. The first measurement was performed one month after the first dose, the second measurement one month after the second dose, the third measurement two months after the second dose, the fourth measurement three months, and the fifth measurement four months after the second dose. Venous blood samples were obtained from participants in $5 \mathrm{~mL} B D$ Vacutainer plastic SST gel tubes, the samples were centrifuged at $3000 \mathrm{rpm}$ for 5 minutes, serum samples were separated, and antibodies were investigated. Total antibodies ( $\lg M$ and $\lg G$ ) against SARS-CoV-2 were quantitatively detected by the electrochemiluminescence immunological (ECLIA) method and the Elecsys ${ }^{\circledR}$ Anti-SARS-CoV-2 kit (Roche Diagnostics GmbH, Germany; Reference Number: 09289267190 containing recombinant protein representing the receptor-binding site (RBD) of $\mathrm{SI}$ antigen. The measurement range of the kit is between $0.40-250 \mathrm{U} / \mathrm{mL}$, and values above $0.80 \mathrm{U} / \mathrm{mL}$ are considered positive in the explanation of the results as recommended by the manufacturer. $^{[10]}$ The specificity of the kit used is $99.98 \%$ and the sensitivity is $98.8 \% .{ }^{[10]}$ Antibody values of $15 \mathrm{U} / \mathrm{mL}$ and above detected by the anti-SARS-CoV-2 $S$ test correlate very well with neutralizing antibodies and are considered a qualified indicator for the presence of neutralizing antibodies: PPA: $88.87 \%$, NPA: $90.00 \%$, PPV: $99.10 \%{ }^{\left[{ }^{11}\right]}$

\section{Statistical analysis}

The NCSS (Number Cruncher Statistical System) program was used for statistical analysis. Descriptive statistical methods (mean, standard deviation, median, frequency, percentage, minimum, maximum) were used while evaluating the research data. The normal distribution conformity of the quantitative data was tested with the Shapiro-Wilk test and the graphical examinations. The Mann-Whitney $U$ test was used for comparisons between two groups of more than two quantitative variables without showing normal distribution. Kruskal-Wallis test and Dunn-Bonferroni test were used for comparisons between groups with more than two quantitative variables not showing normal distribution. The Friedman test was used for intragroup comparisons of quantitative variables that did not show normal distribution, and the Wilcoxon signed-rank test with Bonferroni correction was used for the evaluation of pairwise comparisons. Wilcoxon signed-rank test was used for ingroup comparisons of non-normally distributed quantitative variables. Statistical significance was set to $p<0.05$.

\section{RESULTS}

105 people who received two doses of vaccine in our hospital were invited to the study, and 9 people were excluded from the study because they did not participate in the antibody level measurements on time. Data analysis of a total of 96 participants was performed. The ages of the 96 participants in the study ranged from 22 to 69 (mean $39.75 \pm 11.19)$, with $51 \%(n=49)$ female and $49 \%(n=47)$ male (Table I). The BMI of $48(50 \%)$ participants in the study was $<24.9 \mathrm{~kg} / \mathrm{m}^{2}$ and $48(50 \%)$ were found to be $>25$ $\mathrm{kg} / \mathrm{m}^{2}$. No statistically significant difference was found in the vaccine antibody levels measured at the $I^{\text {st }}, 2^{\text {nd }}, 3^{\text {rd }}, 4^{\text {th }}$, and $5^{\text {th }}$ months of the cases compared to the body mass 
index $(p>0.05)$ in our study. Influenza vaccination rate in volunteers within I month prior to COVID- 19 vaccination was $21.9 \%(n=2 I)$, and male gender $(61.9 \%, n=13)$ and $40-49$ years-old age group $(61.9 \%, n=1) 13)$ was found to be higher. There was no significant difference between the antibody values of the participants and being vaccinated $(p>0.05)$.

\section{Antibody levels}

Measurement I: Antibody concentration measured one month after the first dose of vaccine administration

Antibody positivity was detected in 66 people (68.75\%) after the first dose of vaccination. An antibody concentration higher than $15 \mathrm{U} / \mathrm{mL}$, which is compatible with neutralizing antibodies, was observed in five participants (5.21\%). The mean antibody concentration was found to

Table I. Demographic data of participants

\begin{tabular}{lc}
\hline Demographic data of participants & \\
\hline Gender & $\mathrm{n}(\%)$ \\
Female & $49(5 \mathrm{I} .0)$ \\
Male & $47(49.0)$ \\
Age (years) & \\
Median & $39.75(22-69)$ \\
$20-29$ & $24(25.0)$ \\
$30-39$ & $24(25.0)$ \\
$40-49$ & $27(28.1)$ \\
$\geq 50$ & $21(21.9)$ \\
Body mass index $\left(\mathrm{kg} / \mathrm{m}^{2}\right)$ & \\
$<18.5$ & $2(2.1)$ \\
I8.5-24.9 & $46(47.9)$ \\
$25-29.9$ & $32(33.3)$ \\
$>30$ & $16(16.7)$ \\
Flu vaccination & \\
Yes & $21(21.9)$ \\
No & $75(78.1)$ \\
\hline
\end{tabular}

be $8.93 \pm 35.59 \mathrm{U} / \mathrm{mL}$.

Measurement 2: Antibody concentration measured one month after the second vaccine dose administration

Taking both 0.80 and $15 \mathrm{U} / \mathrm{mL}$ values as cut-off, antibody positivity was found to be $100 \%$ in all individuals participating in the study after the second dose. The mean antibody concentration was $171.30 \pm 81.95 \mathrm{IU} / \mathrm{mL}$.

Measurement 3: Antibody concentration measured two months after the second vaccine dose administration

The antibody positivity of all participants was found to be $100 \%$. The mean antibody concentration was I $25.90 \pm 83.30 \mathrm{IU} / \mathrm{mL}$.

Measurement 4: Antibody concentration measured three months after the second vaccine dose administration

The mean antibody concentration was found to be 98.57 $\pm 80.63 \mathrm{IU} / \mathrm{mL}$.

Measurement 5: Antibodies concentration measured four months after the second dose of vaccine administration

The mean antibody concentration was found to be 89.85 $\pm 83.15 \mathrm{IU} / \mathrm{mL}$ (Table 2). The $162.35 \pm 82.93 \mathrm{U} / \mathrm{mL}$ increase in the vaccine antibody level detected in the first and second measurements was found to be statistically significant $(p=0.001)$. The decreases in vaccine antibody levels detected in the third, fourth and fifth measurements were found to be statistically significant $(p=0.00$ I, Table 2$)$.

It was observed that $68.8 \%(n=66)$ of the individuals who participated in the study had a vaccine antibody level of 0.8 and above in the $I^{\text {st }}$ month, whereas $5.2 \%(n=5)$ had an antibody level of 15 and above.

In the measurements performed a month after the second dose, it was observed that the antibody level of all participants was 15 and above. It was observed that the antibody levels of 90 (93.8\%), 88 (9l.7\%), and 86 (89.6\%) partici-

Table 2. Evaluation of post-vaccine antibody levels by months

\begin{tabular}{|c|c|c|c|}
\hline & \multicolumn{2}{|c|}{ Vaccine antibody levels $(\mathrm{IU} / \mathrm{mL})$} & \multirow[t]{2}{*}{$\mathbf{p}$} \\
\hline & Avg \pm SD & Percentile $\mathbf{2 5 \%} \% \mathbf{7 5} \%$ & \\
\hline Measurement I & $8.93 \pm 35.59$ & $0.6 I-5.93$ & ${ }^{\mathrm{a}} 0.00 \mathrm{I}^{* *}$ \\
\hline Measurement 2 & $171.30 \pm 82.0$ & $106.3-250$ & \\
\hline Measurement 3 & $125.90 \pm 83.30$ & $57.10-206.4$ & \\
\hline Measurement 4 & $98.57 \pm 80.63$ & $33.43-152$ & \\
\hline Measurement 5 & $89.85 \pm 83.15$ & $25.70-121.70$ & \\
\hline $\mathrm{I}^{\text {st }}$ and $2^{\text {nd }}$ measurement difference $(\Delta)$ & $162.35 \pm 82.93$ & $96.92-245.29$ & ${ }^{\circ} 0.00 I^{* *}$ \\
\hline $2^{\text {nd }}$ and $3^{\text {rd }}$ measurement difference $(\Delta)$ & $-45.36 \pm 42.15$ & $-71.82--4.61$ & ${ }^{\mathrm{b}} 0.00 \mathrm{I}^{* *}$ \\
\hline $3^{\text {rd }}$ and $4^{\text {th }}$ measurement difference $(\Delta)$ & $-27.34 \pm 54.33$ & $-52.5--1.02$ & ${ }^{b} 0.00 I^{* *}$ \\
\hline $4^{\text {th }}$ and $5^{\text {th }}$ measurement difference $(\Delta)$ & $-8.72 \pm 44.07$ & $-20.65-0$ & ${ }^{b} 0.00 I^{* *}$ \\
\hline
\end{tabular}


Table 3. Antibody positivity distribution by month

\begin{tabular}{|c|c|c|}
\hline & \multicolumn{2}{|c|}{$\begin{array}{c}\text { Vaccine antibody positivity } \\
\text { distribution }\end{array}$} \\
\hline & $\mathbf{n}$ & $\%$ \\
\hline \multicolumn{3}{|l|}{ Measurement I } \\
\hline$\geq 0.8 \mathrm{IU} / \mathrm{mL}$ & 66 & 68.8 \\
\hline$\geq 15 \mathrm{IU} / \mathrm{mL}$ & 5 & 5.2 \\
\hline \multicolumn{3}{|l|}{ Measurement 2} \\
\hline$\geq 0.8 \mathrm{IU} / \mathrm{mL}$ & 96 & 100.0 \\
\hline$\geq 15 \mathrm{IU} / \mathrm{mL}$ & 96 & 100.0 \\
\hline \multicolumn{3}{|l|}{ Measurement 3} \\
\hline$\geq 0.8 \mathrm{IU} / \mathrm{mL}$ & 96 & 100.0 \\
\hline$\geq 15 \mathrm{IU} / \mathrm{mL}$ & 90 & 93.8 \\
\hline \multicolumn{3}{|l|}{ Measurement 4} \\
\hline$\geq 0.8 \mathrm{IU} / \mathrm{mL}$ & 96 & 100.0 \\
\hline$\geq 15 \mathrm{IU} / \mathrm{mL}$ & 88 & 91.7 \\
\hline \multicolumn{3}{|l|}{ Measurement 5} \\
\hline$\geq 0.8 \mathrm{IU} / \mathrm{mL}$ & 96 & 100.0 \\
\hline$\geq 15 \mathrm{IU} / \mathrm{mL}$ & 86 & 89.6 \\
\hline
\end{tabular}

pants were 15 and above in the subsequent $3^{\text {rd }}, 4^{\text {th }}$, and $5^{\text {th }}$ measurements, respectively (Table 3 ). While there was no significant difference according to gender in the antibody levels measured in the first three months ( $p>0.05)$, the antibody values detected in the $4^{\text {th }}$ and $5^{\text {th }}$ months in women were statistically significantly higher than in men $(p=0.009$ and $p=0.018$, respectively). In general, the vaccine antibody levels of participants aged 50 years and older were significantly lower than those aged 20-29 and 30-39 years ( $p=0.003 ; p=0.031$, respectively). There was no statistically significant difference between the age groups in the $5^{\text {th }}$ month vaccine antibody levels of the cases ( $p>0.05)$.

\section{Patients with post-vaccine COVID-19}

One participant had Polymerase Chain Reaction (PCR) positivity for the SARS-CoV-2 D3L-containing variant (UK variant) 9 weeks after the second vaccine dose. The antibody value detected in the fourth month of this healthcare worker with COVID-19 was $188.2 \mathrm{IU} / \mathrm{mL}$. In one person, 10 weeks after the second vaccine dose, PCR positivity, and clinical signs were not observed despite the close contact with a family member who was PCR positive for the SARS-CoV-2 D3L-containing variant. The antibody level measured in the fourth month of this healthcare worker was $59.35 \mathrm{AU} / \mathrm{mL}$.

\section{DISCUSSION}

In our study, antibody levels against proteins representing the receptor-binding domain of SI antigen were investigated in healthcare workers who received inactivated vaccines. The long-term efficacy of the vaccine and the post-vaccine COVID-19 positivity rate was evaluated. Even after a single dose of inactivated vaccine, up to $70 \%$ of protective antibody positivity was detected. Blood samples taken within one month of the second vaccine dose revealed that all participants were immune to SARSCOV2. This protection continued in the long term after the first dose of vaccine, and the mean antibody value was observed to persist at a high mean value of $89.85 \pm 83.15$ at the end of 5 months. At the end of the fifth month, it was revealed that the rate of individuals who developed neutralizing antibodies was close to $90 \%$.

Phase 1/2 CoronaVac trials in volunteers aged 18-59 years and over 60 years revealed that the vaccine doses examined had similar safety and immunogenicity profiles. ${ }^{[4,12]}$ Subsequently, Phase 3 study results from Turkey were reported. ${ }^{[13]}$ In this study, in which 10218 volunteers were randomly divided into CoronaVac and placebo groups, the vaccine efficacy was determined as $83.5 \%$ I 4 days after the second dose. There were no deaths or grade four adverse events. The most important difference of our study from this large series is that antibody values were also studied after a long 5-month study period. Another large series was studied on the Chilean population. ${ }^{[14]}$ The authors evaluated antibody levels 14 days after the second dose of vaccine, which they considered to be fully immunized. One of the unique features of our study is that the level of protection, which was low in the early period, increased significantly from 2 months after the first dose. However, we report long-term immunization findings.

In a review in which the safety and efficacy of COVID-19 vaccines were discussed, the results of 19 studies of II different vaccines considered to be more than $90 \%$ effective were analyzed. ${ }^{[15]}$ It was concluded that the vaccines in question were well tolerated by the recipients, were effective and safe regardless of age and gender. However, in our study, while there was no significant difference in antibody levels measured in the first 3 months by gender, it was determined that the antibody values detected in the $4^{\text {th }}$ and $5^{\text {th }}$ months in women were significantly higher than in men. In their studies, Takahashi et al. ${ }^{[16]}$ observed that there are significant differences in immune responses during the SARS-CoV-2 infection in male and female patients. Levels of important pro-inflammatory chemokines and cytokines such as IL-8, IL-I8, and CCL5 and monocytes count were higher in male patients. A stronger T-cell response and CD8 cell count were observed in female patients than in male patients. Poor T-cell responses and high innate immune cytokine levels in male patients have been associated with the course and deterioration of COVID-19 disease. The reason for the rapid reduction in antibody levels in men may be related to the differences in the immune systems of men and women. On the other hand, in our study, it was determined that the vaccine antibody levels of the participants aged 50 and over were significantly lower than those between the ages of 20-29 and 30-39. However, there was no significant difference between the age groups in terms of the $5^{\text {th }}$-month vaccine antibody levels of the participants. Pellini et al. ${ }^{[17]}$ reported that the humoral immune response decreases with age and that COVID-19 antibody levels are 
not associated with BMI. In our study, there was no statistically significant difference between vaccine antibody levels according to body mass index. Antibody response may decrease in advanced ages due to the weakening of the immune system. Further studies are needed on the impact of $\mathrm{BMI}$ on the COVID-19 vaccine response.

PCR positivity for the SARS-CoV-2 D3L containing the variant (UK variant) was detected in only one healthcare worker 9 weeks after the second vaccine dose. Two months after the second dose of vaccine, it appeared that the antibody concentration gradually decreased. For this reason, we think that an effective reminder dose for variants at 3 months may be beneficial in those who have received two doses of the vaccine.

\section{Limitations}

Our study had some limitations. First, the participants were generally young and mostly without comorbidities. The average age of the participants was under 40 years. The small sample size was another limitation. It is known that as the number of participants increases, the number of side effects or complications increases. Also, immunity to COVID 19 cannot be explained by antibody levels alone. Therefore, studies investigating immune mechanisms at the cellular level are needed.

\section{CONCLUSION}

As a result, the antibody response is inadequate after the first dose of the inactivated vaccine CoronaVac, while the antibody response increases one month after the second dose. In the long-term follow-up, a significantly high level of neutralizing antibodies even at the end of the $5^{\text {th }}$ month indicates that the vaccine is protective. The decrease in antibody concentrations after vaccination and the emergence of new SARS-COV-2 variants suggest that a booster dose may be beneficial.

Ethics Committee Approval

This study approved by the University of Health Sciences, Istanbul Kartal Dr. Lütfi Kırdar City Hospital Clinical Research Ethics Committee (Date: 24.02.202 I, Decision No: 514/196/20).

\section{Informed Consent}

Prospective study.

Peer-review

Internally peer-reviewed.

Authorship Contributions

Concept: S.D.T., M.M.A., E.Y., K.S., R.D.; Design: S.D.T., M.M.A., E.Y.; Supervision: K.S., R.D.; Fundings: S.D.T.; Materials: S.D.T., M.M.A., E.Y.; Data: S.D.T., M.M.A., E.Y.; Analysis: S.D.T.; Literature search: S.D.T., K.S.; Writing: S.D.T., K.S.; Critical revision: K.S., R.D.

Conflict of Interest

None declared.

\section{REFERENCES}

1. Walker PGT, Whittaker C, Watson OJ, Baguelin M, Winskill P, Hamlet A, et al. The impact of COVID-19 and strategies for mitigation and suppression in low- and middle-income countries. Science 2020;369:413-22. [CrossRef]

2. World Health Organization. Coronavirus disease (COVID-19) numbers at a glance: https://www.who.int/emergencies/diseases/ novel-coronavirus -2019 ?gclid $=$ CjwKCAjw092IBhAwEiwAxR11RngS7sIH8_tlbhPVf1Ii8kc9r73Bm11_XU8ZbBoS__-WnFkC3JRiRoCKRUQAvD_BwE. Accessed Aug 26, 2021.

3. L'Huillier AG, Meyer B, Andrey DO, Arm-Vernez I, Baggio S, Didierlaurent A, et al; Geneva Centre for Emerging Viral Diseases. Antibody persistence in the first 6 months following SARS-CoV-2 infection among hospital workers: a prospective longitudinal study. Clin Microbiol Infect 2021;27:784.e1-8. [CrossRef]

4. Zhang Y, Zeng G, Pan H, Li C, Hu Y, Chu K, et al. Safety, tolerability, and immunogenicity of an inactivated SARS-CoV-2 vaccine in healthy adults aged 18-59 years: a randomised, doubleblind, placebo-controlled, phase $1 / 2$ clinical trial. Lancet Infect Dis 2021;21:181-92. [CrossRef]

5. Long QX, Tang XJ, Shi QL, Li Q, Deng HJ, Yuan J. Clinical and immunological assessment of asymptomatic SARS-CoV-2 infections. Nat Med 2020;26:1200-4. [CrossRef]

6. Asadi Faezi N, Gholizadeh P, Sanogo M, Oumarou A, Mohamed MN, Cissoko Y, et al. Peoples' attitude toward COVID-19 vaccine, acceptance, and social trust among African and Middle East countries. Health Promot Perspect 2021;11:171-8. [CrossRef]

7. Salali GD, Uysal MS. COVID-19 vaccine hesitancy is associated with beliefs on the origin of the novel coronavirus in the UK and Turkey. Psychol Med 2020:1-3. [CrossRef]

8. Akarsu B, Canbay Özdemir D, Ayhan Baser D, Aksoy H, Fidancı I, Cankurtaran M. While studies on COVID-19 vaccine is ongoing, the public's thoughts and attitudes to the future COVID-19 vaccine. Int J Clin Pract 2021;75:e13891. [CrossRef]

9. Haas EJ, Angulo FJ, McLaughlin JM, Anis E, Singer SR, Khan F, et al. Impact and effectiveness of mRNA BNT162b2 vaccine against SARS-CoV-2 infections and COVID-19 cases, hospitalisations, and deaths following a nationwide vaccination campaign in Israel: an observational study using national surveillance data. Lancet 2021;397:1819-29. [CrossRef]

10. Roche. Elecsys Anti-SARS-CoV-2 02289267190 V1.0 Cobas system kit prospectus. In: Roche, editor. 2021. Available at: https://pimeservices.roche.com/eLD/api/downloads/86f4bd63-c5bf-eb110391-005056a772fd?countryIsoCode $=$ tr.

11. Information note: Roche Diagnostic Solutions Research and Development and Product Management Departments Central Laboratory: Correlation between the results of the Elecsys ${ }^{\otimes}$ Anti-SARS-CoV-2 $\mathrm{S}$ test and the detection of functional SARS-CoV-2 neutralizing antibodies. Available at: https://www.klimud.org/public/uploads/ content/files/G\%C3\%BCnsel\%20Veriler-Roche.pdf.

12. Wu Z, Hu Y, Xu M, Chen Z, Yang W, Jiang Z, et al. Safety, tolerability, and immunogenicity of an inactivated SARS-CoV-2 vaccine (Corona $\mathrm{Vac}$ ) in healthy adults aged 60 years and older: a randomised, double-blind, placebo-controlled, phase $1 / 2$ clinical trial. Lancet Infect Dis 2021;21:803-12. [CrossRef]

13. Tanriover MD, Doğanay HL, Akova M, Güner HR, Azap A, Akhan $\mathrm{S}$, et al; Corona Vac Study Group. Efficacy and safety of an inactivated whole-virion SARS-CoV-2 vaccine (CoronaVac): interim results of a double-blind, randomised, placebo-controlled, phase 3 trial in Turkey. Lancet 2021;398:213-22. [CrossRef]

14. Jara A, Undurraga EA, González C, Paredes F, Fontecilla T, Jara G, et al. Effectiveness of an inactivated SARS-CoV-2 vaccine in Chile. 
N Engl J Med 2021 Jul 7 [Epub ahead of print], doi: 10.1056/ NEJMoa2107715. [CrossRef]

15. Doroftei B, Ciobica A, Ilie OD, Maftei R, Ilea C. Mini-review discussing the reliability and efficiency of COVID-19 vaccines. Diagnostics (Basel) 2021;11:579. [CrossRef]

16. Takahashi T, Ellingson MK, Wong P, Israelow B, Lucas C, Klein J, et al. Sex differences in immune responses that underlie COVID-19 disease outcomes. Nature 2020;588:315-20. [CrossRef]

17. Pellini R, Venuti A, Pimpinelli F, Abril E, Blandino G, Campo F, et al. Initial observations on age, gender, BMI and hypertension in antibody responses to SARS-CoV-2 BNT162b2 vaccine. EClinicalMedicine 2021;36:100928. [CrossRef]

\section{İnaktif COVID-19 Aşısı (CoronaVac) Olan Sağlık Çalışanlarında SARS CoV-2 Spike Proteine Karşı Gelişen Antikorların Saptanması ve Değerlendirilmesi}

Amaç: S proteini bir transmembran proteini olup bu proteine karşı gelişen antikorlar, aşı sonrası ve geçirilmiş enfeksiyon sonrası bağışıklığı araştırmak için kullanılmaktadır. Bu çalışmada sağlık çalışanlarında CoronaVac aşısı sonrası antikor düzeylerinin ve aşının etkinliğinin araştırıması amaçlanmıştır.

Gereç ve Yöntem: CoronaVac aşısı uygulanmış, 96 sağlık personeline ait verinin analizi yapılmıştır. İki aşı dozu arasında 28 gün bırakılarak birinci dozdan itibaren beş aylık periodda aylık antikor ölçümleri yapıldı. SARS-CoV-2'ye karşı oluşan total antikorlar (IgM ve lgG), elektrokemilüminesans yöntemi ve SI antijeninin reseptör bağlanma alanını temsil eden rekombinant protein içeren Elecsys ${ }^{\circledR}$ Anti-SARS-CoV-2 S kiti ile saptandı ve karşılaşııııldı.

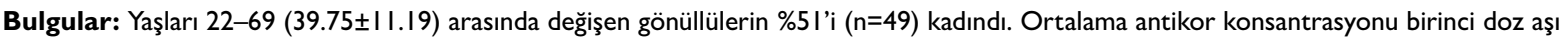
uygulamasından bir ay sonra $8.93 \mathrm{U} / \mathrm{mL}$, ikinci doz aşıdan bir ay sonra $171.30 \mathrm{IU} / \mathrm{mL}$, ikinci doz aşıdan iki ay sonra $125.90 \mathrm{IU} / \mathrm{mL}$, üç ay sonra $98.57 \mathrm{IU} / \mathrm{mL}$, dört ay sonraysa $89.85 \mathrm{IU} / \mathrm{mL}$ olarak tespit edilmiştir. Birinci ve ikinci aylarda antikor düzeylerindeki artış; üçüncü, dördüncü ve beşinci aylarda antikor düzeylerindeki azalmalar istatistiksel olarak anlamlı bulunmuştur. Antikor pozitifliği $\geq 0.8 \mathrm{IU} / \mathrm{mL}$ gözlenen ve nötralizan antikor ( $\geq 15 \mathrm{lU} / \mathrm{mL}$ ) gelişen gönüllülerin oranı ilk doz aşı sonrası \%68.75 ve \%5.2I olarak bulunmuştur. Nötralizan antikor geliştiren birey oranı, ikinci doz aşı sonrası ise aylara göre \%। 00 , \%93.8, \%91.7 ve \%89.6 şeklindedir. Bir kişide, ikinci doz aşıdan dokuz hafta sonra SARSCoV-2 D3L içeren varyant (İngiltere varyantı) PCR pozitifliği saptanmıştır.

Sonuç: Uzun süreli takiplerde nötralizan antikor seviyesinin beşinci ayın sonunda dahi anlamlı olarak yüksek bulunması aşının koruyucu olduğunu göstermektedir. Aşı sonrası antikor konsantrasyonlarının düşmesi ve SARS-COV-2'nin yeni varyantlarının ortaya çıkması, destek aşı dozunun faydalı olabileceğini düşündürmektedir.

Anahtar Sözcükler: Antikor tespiti; CoronaVac; immünite; inaktif aşı; SARS-CoV-2. 